\title{
Fish Supply Chain Model in Traditional Market: Case Study of Beringharjo Market Yogyakarta
}

\author{
Ensi Saraswati, and Suadi* \\ Department of Fisheries, Faculty of Agriculture, Universitas Gadjah Mada, Indonesia
}

\begin{abstract}
This research aimed to understand the flow of fish commodity, information, and financial in the fish supply chain at the traditional market, through case study in the Beringharjo market Yogyakarta. Data was collected through systematic interview with 18 fish businesspersons and observation on the study site. The study showed fish commodities in the market consisted of marine, freshwater and processed fish (salted/dried fish and soft bone milkfish/bandeng presto). The fish majorly supplied by suppliers from outside Yogyakarta, that reached $86-90 \%$ for fresh fish (marine and freshwater) and 100\% for salted fish and raw material of bandeng presto. Suppliers and traders in Beringharjo market used flexible methods of payment, such as manual receipt and trust-based relation (for instance pay on other day). The suppliers and traders had been work together for more than five years. The emerging problems were the lack of fresh fish supply and the low quality of processed fish. The supply chain model for fresh fish involved three stages (supplier-seller-ultimate customer/household) and the supply chain model for processed fish in four stages (supplier-wholesaler-trader/seller-ultimate consumer). The supply chain model for the milkfish also consisted of four stages (supplier-fish processor-seller-ultimate consumer). The study indicates the importance of improving local fish production systems to fullfill growing fish consumption in DIY.
\end{abstract}

\section{Introduction}

The Special Region of Yogyakarta (DIY) is geographically bordered by the Indian Ocean on the southern coast of Java. Despite the direct access to the seas, fisheries are not the main livelihood of the people and therefore, the current fish production is under the maximum potential yield of the fishery resources. In the meantime, the current fish consumption in DIY is also one of the lowest groups in Indonesia (national average 46.49 per capita and DIY 23.75 per capita in 2017) [1], but increase significantly year to year. Bappeda DIY (2019) indicated that fish consumption in DIY grew from $17.16 \mathrm{~kg} / \mathrm{capita}$ in 2014 , to $23.10 \mathrm{~kg} / \mathrm{capita}$ in 2016, and in 2018 reached $24.05 \mathrm{~kg} /$ capita [2]. The low level of per capita fish consumption is caused by several factors, one of them is the availability of the fish. The activities of fish farming, fish processing, and fishing in this province are not able yet to fulfill consumer demand. Therefore, various fish commodities are imported from area surrounds.

*Corresponding author: suadi@ugm.ac.id 
Traditional markets play important roles as a marketplace of various commodities and channeling those commodities from many places to customers. In fact, USDRP Ministry of Public Affairs stated traditional market contribute significant roles as a place where all people get daily necessities at relatively affordable prices; as more accessible places by weak economic actors who occupy the majority position in terms of numbers; and as indicator of economic growth at local, regional and national scale [3]. Therefore, traditional markets also provide various fish commodities, from fresh fish to processed fish products, for various segments of consumers. The study of fish supply chain management is needed to fulfill the customers need and at the same time to reduce the operating costs of business activities. Bowersox et al. (2013) have highlighted that the modern supply chains need more attention to consumers, to answer their needs, that tend to want more choices [4]. In addition, companies that are able to survive and be sustainable in managing their business are those that are able to manage their supply chains in an integrated way by reducing non-added values (waste) while simultaneously maximizing value-added activities [5].

Research about the fish supply chain in Special Region of Yogyakarta is very rare and necessary to be conducted, in order to know the facility network and the fish distribution, the information in supplying fish, and the processing that process the raw material into final products. Marimin (2010) mentioned that supply chain management is the whole production process, starting from the time the fish is processed, distributed, and purchased by the consumer as the final product [6]. This paper will describe fish supply model in the traditional market, through a case study in Beringharjo market, in order to understand the flow of information, products, and financial in the Beringharjo's fish supply chain, to identify the main problem of fish supply chain management, and to build the model of fish supply chain in this market.

\section{Materials and Methods}

This research was conducted in November 2017 until May 2018. The method used in this research is a case study, in which data collection gathered from interviews and observation. All the fish businessperson in the market was interviewed, with the total number of respondent 18 people ( 4 respondents of freshwater fish business, 8 respondents of process fish business, and 6 suppliers). There are two kinds of data sources used in this paper; primary and secondary. The primary data is obtained from the interview with the respondent and observation. Meanwhile, the secondary data is gathered from various statistics and references about the fish supply chain. The data analysis used in this study is a descriptive analysis.

\section{Results}

\subsection{Flow of Fish Product in Beringharjo Market}

The flow of fish product includes the source of fish, amount of fish (volume of fish supplied), the quality of fish, the timeliness of delivery system, and the continuity of fish supply. The flow of fish is categorized based on the type or kind of commodity. The first category is fresh fish, which includes marine fish and freshwater fish. The second category is processed fish, which includes salted fish and milkfish presto/milkfish soft bones (bandeng presto). The flow of fish in Beringharjo market is shown in Table 1. 
Table 1. The Supply Flow of Fish in Beringharjo Market.

\begin{tabular}{|c|c|c|c|c|c|}
\hline \multirow[b]{2}{*}{ No } & \multirow[b]{2}{*}{$\begin{array}{c}\text { Description of } \\
\text { Flow }\end{array}$} & \multicolumn{4}{|c|}{ Commodity } \\
\hline & & $\begin{array}{c}\text { Fresh Marine } \\
\text { Fish }\end{array}$ & Freshwater Fish & Salted Fish & Milkfish Presto \\
\hline 1 & $\begin{array}{l}\text { The source of } \\
\text { fish }\end{array}$ & $\begin{array}{l}86 \% \text { comes } \\
\text { from places } \\
\text { outside of the } \\
\text { province } \\
\text { (mostly } \\
\text { Semarang), } 14 \\
\% \text { comes from } \\
\text { places within } \\
\text { the province }\end{array}$ & $\begin{array}{l}90 \% \text { comes } \\
\text { from places } \\
\text { outside of the } \\
\text { province, } 10 \% \\
\text { comes from } \\
\text { places within } \\
\text { the province }\end{array}$ & $\begin{array}{l}100 \% \text { comes } \\
\text { from places } \\
\text { outside of the } \\
\text { province }\end{array}$ & $\begin{array}{l}100 \% \text { raw fish } \\
\text { comes from } \\
\text { places outside } \\
\text { of the province } \\
100 \% \text { processed } \\
\text { fish comes from } \\
\text { places within } \\
\text { the province }\end{array}$ \\
\hline 2 & $\begin{array}{l}\text { The quantity } \\
\text { of fish }\end{array}$ & 3-4 quintal/day & $\begin{array}{l}1,5-3 \\
\text { quintal/day }\end{array}$ & $\begin{array}{l}2,5-3,5 \\
\text { quintal/day }\end{array}$ & $\begin{array}{l}15-72 \\
\text { kilogram/day }\end{array}$ \\
\hline 3 & $\begin{array}{l}\text { The quality of } \\
\text { fish }\end{array}$ & $\begin{array}{l}\text { Fish with poor } \\
\text { quality will be } \\
\text { returned/sold at } \\
\text { low } \\
\text { price/thrown } \\
\text { away }\end{array}$ & $\begin{array}{l}\text { Fish with poor } \\
\text { quality will be } \\
\text { returned/sold at } \\
\text { low } \\
\text { price/thrown } \\
\text { away }\end{array}$ & $\begin{array}{l}\text { Fish with poor } \\
\text { quality will be } \\
\text { returned/sold at } \\
\text { low price }\end{array}$ & $\begin{array}{l}\text { Fish with poor } \\
\text { quality will be } \\
\text { returned }\end{array}$ \\
\hline 4 & Delivery time & $\begin{array}{l}\text { On-time, } \\
\text { around } 03.00 \\
\text { WIB }\end{array}$ & $\begin{array}{l}\text { On-time, } \\
\text { around } 03.00 \\
\text { WIB }\end{array}$ & $\begin{array}{l}\text { Depends on the } \\
\text { supplier }\end{array}$ & $\begin{array}{l}\text { At } 05.00 \text { and } \\
19.00 \mathrm{WIB}\end{array}$ \\
\hline 5 & $\begin{array}{l}\text { The } \\
\text { continuity of } \\
\text { fish supply }\end{array}$ & Sustained & Sustained & Sustained & Sustained \\
\hline
\end{tabular}

The study showed that $86 \%$ of marine fish sold in Beringharjo Market came from places outside of the province (especially Semarang), and only $14 \%$ of them came from places within the province. Similarly, most of the freshwater fish came from places outside of the province (90\%), particularly from Klaten and Boyolali (Central Java), and only $10 \%$ comes from local sellers who cultivate fish. Processed fish particularly salted fish and raw material of milkfish presto all came from places outside of Yogyakarta province. The main suppliers come from East and Central Java Java (Tuban, Demak, Pasuruan, Kendal, and Madura) and West Java particularly from Pangandaran. Raw materials for the milkfish presto were supplied by Gresik (East Java Province) and Juwana fish farmer (Central Java Province). The fish trader and processor in Beringharjo Market heavily relied on the raw materials from outside DIY because of the lack of availability of the commodity in the province. Indeed, the capture fishery in Yogyakarta is not well-developed (Suadi 2002) [7]. In addition, aquaculture production is still low, which is only 88.550 tons in 2017 , compared to other provinces surround, such as Central Java produces 485.690 tons of fish from its fish farming, while East Java produces 1.189.443 tons [8].

Different kinds of commodities required different processes of ordering and delivering. Fresh fish was majorly delivered early in the morning, during 02.00-04.00am by using a small truck. Each truck carried about 200-300 kilograms of fish. Various kinds of raw fish were stored in the barrel, and carriers (usually the suppliers themselves or their workers), will bring the fish down and deliver them to the merchant/trader stalls. The person in charge who carried the fish will give the bill to the Beringharjo fish traders. If they do not meet the traders during delivery time, the bill will be given at noon. For salted fish, the supplier will regularly have sent the product to the traders in Beringharjo. The suppliers usually come at noon, bringing salted fish wrapped in teak leaves. Meantime, milkfish presto will be delivered at $05.00 \mathrm{am}$ to the Beringharjo market, and the product placed on the wooden tray. On average, there are 
15-72 kilograms of milkfish presto sent to the market, daily. The processor relied on the raw material from suppliers outside of the Yogyakarta region. In relation to the quality of fresh fish, the traders usually returned poor quality fish to the supplier. However, sometimes, the traders even sell the fish very cheap to prevent financial loss.

\subsection{Cash Flow of Fish Supply Chain In Beringharjo Market}

The cash flow discussed in this research included payment method, payment period, the system of relationship selling, and debt system. More detailed information about the cash flow is explained in Table 2:

Table 2. The Cash Flow of Fish in Beringharjo Market

\begin{tabular}{|c|l|l|l|l|l|}
\hline \multirow{2}{*}{ No } & \multirow{2}{*}{ Cash Flow } & \multicolumn{4}{|c|}{ Commodity } \\
\cline { 3 - 6 } & $\begin{array}{c}\text { Fresh } \\
\text { Marine Fish }\end{array}$ & $\begin{array}{c}\text { Freshwater } \\
\text { Fish }\end{array}$ & \multicolumn{1}{|c|}{ Salted Fish } & Milkfish Presto \\
\hline 1 & Payment method & $\begin{array}{l}\text { Paid next } \\
\text { day }\end{array}$ & $\begin{array}{l}\text { Paid next } \\
\text { day }\end{array}$ & Cash & Cash \\
\hline 2 & Payment period & 1 day & 1 day & 1 day/1 week & 1 week \\
\hline 3 & $\begin{array}{l}\text { The system of } \\
\text { relationship selling }\end{array}$ & Mutual trust & Mutual trust & Mutual trust & Mutual trust \\
\hline 4 & Debt system & Flexible & Flexible & Flexible & Flexible \\
\hline 5 & Margin & $\begin{array}{l}\text { Rp1.500- } \\
3.000 / k g\end{array}$ & $\begin{array}{l}\text { Rp1.300- } \\
3.000 / k g\end{array}$ & Rp2.000/kg & $\begin{array}{l}\text { Rp2.000- } \\
3.000 / k g\end{array}$ \\
\hline
\end{tabular}

Usually, the payment method for fresh fish, both marine and freshwater fish is locally called ngalap nyaur or paid the next day. Ngalap nyaur is a Javanese term, which means the goods that come today will be paid on the next day. Usually, the suppliers of fresh fish prefer to paid with this method to prevent debt accumulation. Meanwhile, the suppliers of salted fish and milkfish presto prefer to paid cash on the same day they deliver the fish.

The payment period for fresh fish is only 1 day, whereas salted fish and milkfish presto have longer payment period, which is up to 1 week. In running the business, the suppliers and the traders in Beringharjo market had such mutual trust. Such social capital (trust-based) emerged because the traders have become loyal customers of the suppliers for a long period of time (more than five years). Other than that, the family business also plays an important role. Sometimes, the suppliers have supplied the fish for the previous generation of the traders' family. This condition makes the debt system becomes more flexible.

\subsection{Information Flow of Fish in Beringharjo Market}

Information flow is a very important aspect when studying the supply chain. The information flow discussed in this research includes the source of information, information processing, and order processing. In this context, the source of information is about how the fish trader in Beringharjo Market contact the suppliers and the customers. The information processing is about how the actors involved in the transaction process provided information. The order processing is about how the traders in the market order the fish from the suppliers. Meanwhile, the deal between actors is about how the fish trader in Beringharjo market making deal with parties involved in the transaction. The information flow of the fish supply chain in Beringharjo Market is described in the following table: 
Table 3. The Information Flow of Fish in Beringharjo Market

\begin{tabular}{|c|l|l|l|l|l|}
\hline \multirow{2}{*}{ No } & \multirow{2}{*}{$\begin{array}{c}\text { Information } \\
\text { Flow }\end{array}$} & $\begin{array}{l}\text { Fresh Marine } \\
\text { Fish }\end{array}$ & Freshwater Fish & \multicolumn{1}{|c|}{ Salted Fish } & Milkfish Presto \\
\hline 1 & $\begin{array}{l}\text { The source of } \\
\text { information }\end{array}$ & $\begin{array}{l}\text { Information } \\
\text { mostly comes } \\
\text { from the } \\
\text { suppliers }\end{array}$ & $\begin{array}{l}\text { Information } \\
\text { mostly comes } \\
\text { from the } \\
\text { suppliers }\end{array}$ & $\begin{array}{l}\text { Information } \\
\text { mostly comes } \\
\text { from the } \\
\text { suppliers }\end{array}$ & $\begin{array}{l}\text { Information } \\
\text { mostly comes } \\
\text { from the } \\
\text { processor who } \\
\text { has a familial } \\
\text { relationship } \\
\text { with the traders }\end{array}$ \\
\hline 2 & $\begin{array}{l}\text { The order } \\
\text { processing }\end{array}$ & $\begin{array}{l}\text { Daily short } \\
\text { message, } \\
\text { phone call, or } \\
\text { online } \\
\text { messenger } \\
\text { such as } \\
\text { Whatsapp }\end{array}$ & $\begin{array}{l}\text { Daily short } \\
\text { message, phone } \\
\text { call, or Whatsapp }\end{array}$ & $\begin{array}{l}\text { Short message, } \\
\text { phone call, or } \\
\text { Whatsapp every } \\
\text { two days or } \\
\text { directly order } \\
\text { the fish from } \\
\text { other salted fish } \\
\text { traders }\end{array}$ & $\begin{array}{l}\text { Short message, } \\
\text { phone call, or } \\
\text { Whatsapp a day } \\
\text { before the fish } \\
\text { are delivered }\end{array}$ \\
\hline 3 & $\begin{array}{l}\text { The deal } \\
\text { between actors }\end{array}$ & $\begin{array}{l}\text { Creating a bill } \\
\text { for every } \\
\text { purchase }\end{array}$ & $\begin{array}{l}\text { Creating a bill for } \\
\text { every purchase }\end{array}$ & $\begin{array}{l}\text { Creating a bill } \\
\text { and recording it } \\
\text { on purchases } \\
\text { book for every } \\
\text { purchase }\end{array}$ & $\begin{array}{l}\text { Creating a bill } \\
\text { for every } \\
\text { purchase }\end{array}$ \\
\hline
\end{tabular}

Sources of information for fresh fish were mostly coming from suppliers. Suppliers play important roles because of their rich knowledge about the fish stocks in the market and fish price. For milkfish presto, the information also comes from families, because suppliers are part of the family of traders in the Beringharjo Market. In fact, suppliers in the Beringharjo market are suppliers that have been subscribed for a long time. Fish traders order fish from suppliers using short messages (SMS), telephone or Whatsapp (WA) because it is more practical and efficient. Traders have several requirements that must be met by suppliers including the quality of fish, size, and continuity in shipping goods.

\subsection{Supply Chain Model of Fresh Fish}

The supply chain model of fresh fish is divided into four groups: fresh marine fish, freshwater fish, and salted fish, and milk-fish soft bones or bandeng presto.

\subsubsection{Fresh Marine Fish}

The supply chain model of fresh marine fish in Beringharjo Market is illustrated in the following diagram. 


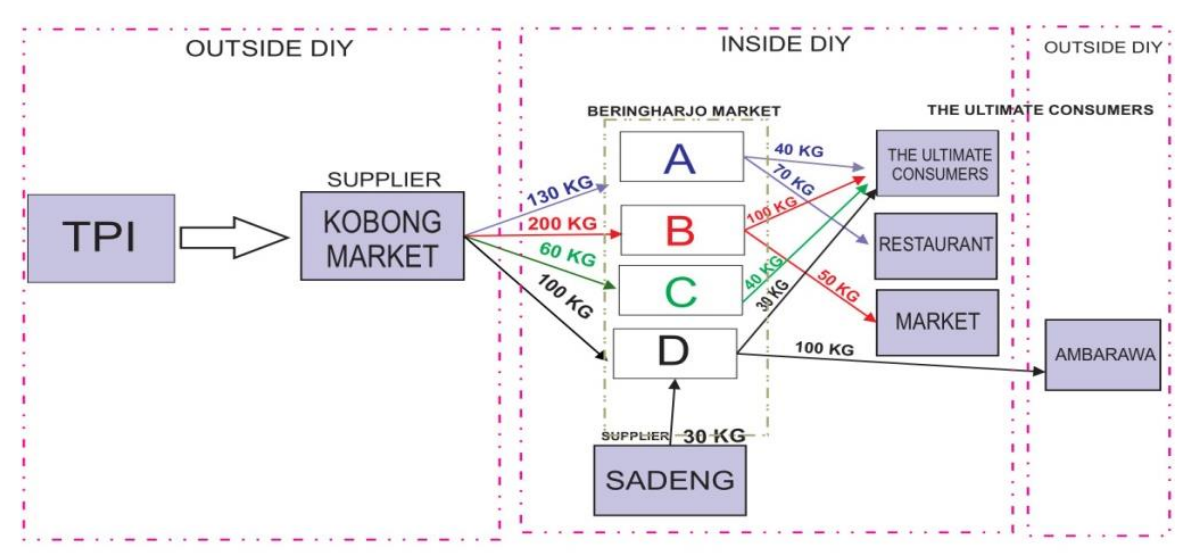

Fig. 1. Supply chain model of raw marine fish in Beringharjo Market.

The marine fresh fish in Beringharjo market majorly came from Kobong Market (Semarang, Central Java), either supplied by suppliers from that market and/or traders/local suppliers directly buy at the market. The Kobong Market usually is the central market of fish on the southern coast of Java. On average each trader orders fish of about 60-130 kilograms per day and distributed to consumers about 30-100 kilograms. Traders stock about 20-50 kilograms of fish as safety stock. The general pattern of the fish supply chain described as follows:
a. Fishers - fish auction - Kobong Market (wholesaler)- suppliers - traders in Beringharjo Market - consumers
b. Fisher in Yogyakarta (Sadeng) - suppliers - traders in Beringharjo Market - consumers

\subsubsection{Freshwater Fish}

Supply chain model of freshwater fish in Beringharjo Market is illustrated in the following diagram:

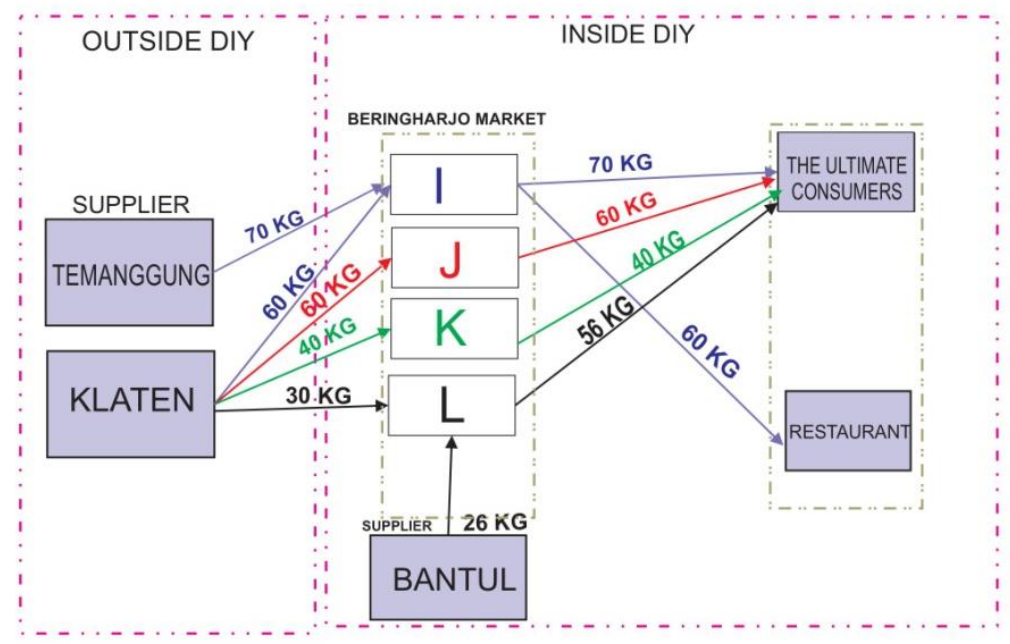

Fig. 2. Supply chain model of raw fresh water fish in Beringharjo Market. 
In general, the supply chain of freshwater fish includes some actors: fishers, wholesalers, suppliers, traders, and consumers. Most of the fish production came through freshwater aquaculture. The pattern of the supply chain can be described as follows:

a. Temanggung/Klaten supplier (Yoyakarta out region supplier) - traders in Beringharjo Market - consumers

b. Bantul supplier (in Yoyakarta supplier) -traders in Beringharjo Marketconsumers

\subsubsection{Salted Fish}

Supply chain model of raw salted fish in Beringharjo Market is illustrated in the following diagram:

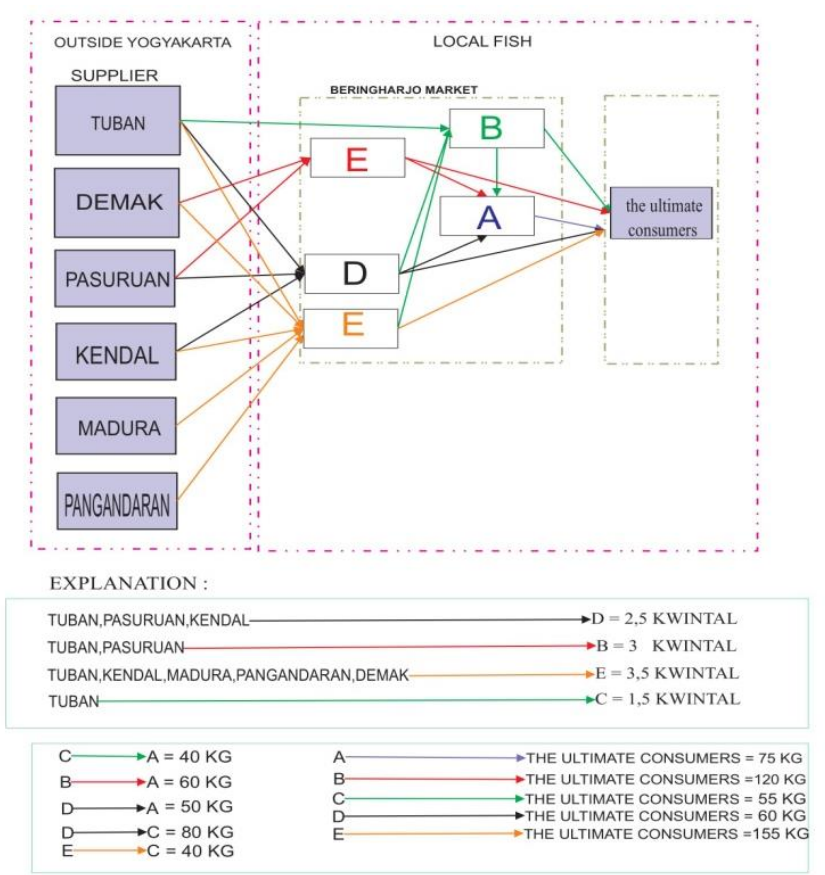

Fig. 3. Supply chain model of raw salted fish in Beringharjo Market.

According to Figure 3, salted fish all came from outside of Yogyakarta province, which includes Tuban, Pasuruan, and Madura (East Java), Demak and Kendal (Central Java), and Pangandaran (East Java). Some salted fish traders in Beringharjo Market were also suppliers. Such traders majorly have a warehouse as storage near the sales location. Salted fish traders in this market also bought salted fish from other traders who are larger-scale traders. On average, large scale traders supplied other traders in Bringharjo and other traditional markets around 40-80 kilogram in every two days. In general, the description of the supply chain model of salted fish can be seen in the following list:

a. Salted fish processors - supplier - traders in Beringharjo Market - consumers

b. Salted fish processors - supplier - wholesalers in Beringharjo Market - traders in Beringharjo Market - consumers

c. Salted fish processors - supplier - wholesalers in Beringharjo Market - traders in other Market in Yogyakarta - consumers 


\subsubsection{Milk-fish Soft Bones}

Supply chain model of raw milk-fish soft bones in Beringharjo Market is illustrated in the following diagram:

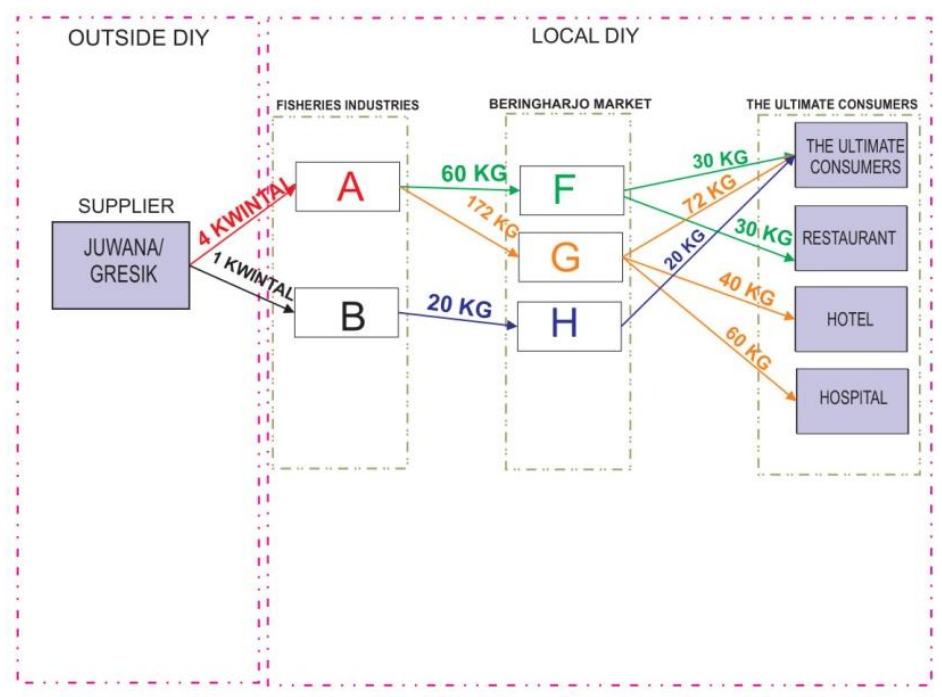

Fig. 4. Supply chain model of raw milk-fish soft bones in Beringharjo Market

The production of milkfish presto in Yogyakarta, in relation to the supply chain in Berigharjo market has two steps. The first step was providing raw material, which was fresh or frozen milkfish. The second step was processing raw materials into presto milkfish in the fish processing unit (UPI) and then delivered to the traditional markets, including Beringharjo. All of the fresh milkfish were supplied by the out-region supplier (may reach 100-400 kilograms per day from Juwana Central Java and Gresik East Java), while $100 \%$ of the milkfish presto was processed in Yogyakarta. After going through several cooking processes, Presto milkfish was distributed to Beringharjo Market for 1.5 quintals per day. Each trader orders milkfish with different volumes of bandeng presto, ranging from 20 kilograms to 172 kilograms per day. Presto milkfish were not only distributed to end consumers (households) but also distributed to hospitals, hotels and restaurants. However, for hospitals and hotels order milkfish presto only two times in a month, for about 40-60 kg per order. Based on this study, there are eight main types of supply chain models for milkfish presto:
a. Farmers - collectors -fish processing units - traders in Beringharjo Market - consumers
b. Farmers - collectors - small fish processing units - traders in Beringharjo Market - hospitals
c. Farmers - collectors - small fish processing units - traders in Beringharjo Market - restaurants - consumers
d. Farmers - collectors - small fish processing units - traders in Beringharjo Market - hotels
e. Farmers - small fish processing units - traders in Beringharjo Market - consumers
f. Farmers - small fish processing units - traders in Beringharjo Market - restaurants
g. Farmers - small fish processing units - traders in Beringharjo Market - hospitals
h. Farmers - small fish processing units - traders in Beringharjo Market - hotels 
Overall, the study showed that Beringharjo market, as a traditional market in the central part of Yogyakarta, has contributed significant roles as a marketplace for various fish commodities. Fresh fish included marine fish such as tuna, skipjack, shrimp, squids, snapper, grouper, and mackerel; and freshwater fish such as tilapia, catfish, and gourami; and processed fish consisting of salted fish and milkfish presto. The majority of fish commodities sold in the Beringharjo Market were originating from outside DIY (only 10-14\% from within DIY). The average demand of Beringharjo Market for fresh marine fish was about 3-4 quintal per day, 1.5-3 quintal per day for freshwater fish, and salted fish about 2.5-3.5 quintal per day, and presto milkfish for about 15-72 kg per day. Such figures created two main issues in the fish supply chain management: (1) the risk issues related to the continuity of fish supply because of high dependency on the fish product from out-region in one hand and lack of local supply on the other hand, and (2) risk issues related to the quality of the fish product because of the length current supply chain model. Suwondo et al. (2016) indicated the risk of the fresh fish product supply chain was mainly caused by unnecessary processes, delay, and product defects due to improper storage processes [9]. Therefore, it is important for DIY to improve fishery production both from aquaculture as well as capture fisheries through the improvement of fishery productivity.

The study also found that the relationship between supplier and trader in Beringharjo market tended to be more flexible and principally rely on trust among the actors (businessperson). Such trust-based has been identified as a significant predictor of positive performance in business relationships, including in the higher performance in the supply chain [10]. Therefore, strengthening cooperation between actors is needed to ensure the supply of fish is maintained at standard quality and in accordance with consumer needs.

\section{Conclusions}

The study identified that the traders in Beringharjo Market get information about suppliers from their relatives, family, and suppliers. The payment method tends to be more flexible and using bills. The parties involved in this transaction rely on mutual trust. The fish in Beringharjo Market comes from both outside Yogyakarta and within Yogyakarta, but majorly fish as raw material imported from out-region of DIY. It is count about $86 \%$ of fresh marine fish and $90 \%$ of freshwater fish came from other provinces. Meanwhile, $100 \%$ of the raw material for milkfish presto comes from other provinces.

There are two main challenges in the fish supply chain in the traditional market such as Beringharjo market, mainly: the continuity of fresh fish supply and poor quality of the fish product. The supply chain model of fresh fish in Beringharjo Market has three steps: suppliers, traders, and consumers. Meanwhile, the supply chain model of processed fish has 4 steps: suppliers, wholesalers, traders, and consumers. As for the milkfish, the supply chain model includes suppliers, small fish processing units, traders, and consumers.

Based on the study, we propose that the Beringharjo Market needs to build and promote a better cold chain system in order to guarantee the quality of fish. However, market management should make sure that this facility does not cost much to the traders. As the high dependency on the fish supply from the out-region of DIY, the improvement of the fishery production system should become the main priority of DIY government. In addition, traders in Beringharjo market need to extend fish suppliers from other places, not only from Semarang to ensure the sustainability of fish supply. 


\section{References}

1. PDSPKP, Produktivitas Perikanan Indonesia. Ministry of Marine Affairs and Fisheries Republic of Indonesia. https://kkp.go.id/wp-content/uploads/2018/01/KKP-DirjenPDSPKP-FMB-Kominfo-19-Januari-2018.pdf. Accessed October 2019

2. http://bappeda.jogjaprov.go.id/dataku/data dasar/cetak/558-tingkat-konsumsi-ikan. Accessed October 2019.

3. USDRP. Pedoman Umum Manajemen Pasar. Profesinalisasi Manajemen Aset Pasar dan Terminal. $\quad$ https://id.scribd.com/doc/115097125/Pedoman-Umum-ManajemenPengelolaan-Pasar. Accessed October 2019.

4. D.J. Bowersox, D.J. Closs, M.B. Cooper, Supply Chain Logistics Management. (McGraw Hill, New York, 2013).

5. J. Heizer, R. Barry, and C. Munson. Operations Management: Sustainability and Supply Chain Management. 12th Edition. (Prentice Hall Inc, New Jersey, 2017).

6. Marimin , N. Magfiroh. Aplikasi Teknik Pengambilan Keputusan dalam Manajemen Rantai Pasok, (IPB Press, Bogor, 2010).

7. Suadi, Dari Petani Menjadi Nelayan: Kajian Historis Perikanan Tangkap Pantai Selatan Yogyakarta (2002).

8. https://www.bps.go.id/dynamictable/2019/05/16/1624/produksi-perikanan-budidayamenurut-provinsi-dan-jenis-kegiatan-2017.html. Accessed October 2019

9. E. Suwondo, H. Yuliando, and F.J Saputro, 2016. Analysis of risk in the value stream of supply chain management of marine fresh fish product, case of coastal zone, Java Island, Indonesia. AIP Conference Proceedings 1755, 130011 (2016); https://doi.org/10.1063/1.4958555.

10. P.M. Panayides, Y.H.V. Lun, 2009. The impact of trust on innovativeness and supply chain performance. International Journal of Production Economics 122(1): 35-46. 